\title{
Strengthening of Sintered Austenitic Stainless Steels through Low-Temperature Carburization
}

\author{
Li-Hui Cheng*1 and Kuen-Shyang Hwang*2 \\ Department of Materials Science and Engineering, National Taiwan University, \\ 1, Roosevelt Road, Sec. 4, Taipei, 106, Taiwan, R. O. China
}

The tensile strength and hardness of pressed-and-sintered 316L and 304L are generally poor due to the low sintered density and austenitic structure. To improve these properties, low-temperature carburization (LTC) was applied to these materials. In contrast to fully dense parts, for which LTC can increase the surface hardness with only limited depth, carbon can effectively diffuse into the center of pressed-and-sintered specimens through interconnected pores and harden all pore surfaces inside the compact. For sintered $316 \mathrm{~L}$ with a density of $6.71 \times 10^{3} \mathrm{~kg} / \mathrm{m}^{3}$, the hardness increased from 25 to $75 \mathrm{HRB}$ (from HV70 to HV137) and the tensile strength increased from 295 to $520 \mathrm{MPa}$ after LTC, while the corrosion resistance remained almost the same because no chromium carbide formed. The hardness and tensile strength of sintered 304L were also improved after LTC. For sintered 304L with a density of $6.70 \times 10^{3} \mathrm{~kg} / \mathrm{m}^{3}$, the hardness increased from 27 to 74 HRB (from HV72 to HV135), and the tensile strength increased from 291 to 519 MPa. The bulk hardness and tensile strength of the high-density part were lower than those with a low density, since less carbon could diffuse into the center and fewer carburized regions formed. [doi:10.2320/matertrans.M2011150]

(Received May 19, 2011; Accepted October 14, 2011; Published November 30, 2011)

Keywords: powder metallurgy, stainless steel, low-temperature carburization

\section{Introduction}

The use of powder metallurgy (PM) for fabricating 316L and $304 \mathrm{~L}$ stainless steels minimizes the need for machining and deformation operations and thus allows economical production of net-shaped products. ${ }^{1)}$ While PM austenitic stainless steels have good corrosion resistance, the hardness and strength are in general relatively low compared to those of wrought materials due to the porosity, austenitic structure, and large grains caused by high temperature sintering. For pressed-and-sintered $316 \mathrm{~L}$ with a density of $6.9 \times 10^{3} \mathrm{~kg} / \mathrm{m}^{3}$, the typical hardness, tensile strength, and elongation are $45 \mathrm{HRB}$ (HV87), $390 \mathrm{MPa}$, and $21 \%$, respectively. ${ }^{2)}$ The low hardness and strength impose limitations on the application of PM austenitic stainless steels.

It has been shown that carburization of wrought austenitic stainless steels at low-temperatures, usually lower than $823 \mathrm{~K}$, improves the surface hardness remarkably. ${ }^{3-6)}$ Michal et al. demonstrated that substitutional solutes, such as $\mathrm{Cr}$ and $\mathrm{Ni}$, were immobile during low-temperature carburization (LTC), whereas interstitial solutes, such as carbon, were still transportable and could increase the surface hardness of the parts. ${ }^{7)}$ Cao et al. carburized 316 stainless steels at $743 \mathrm{~K}$ for $886 \mathrm{ks}$; the surface hardness increased from HV200 to HV1000 and the carburized layer was about $70 \mu \mathrm{m} .{ }^{6)}$ The hardened surface layer contained an expanded FCC structure with significant amounts of residual stresses present in it due to the large amounts of entrapped carbon. ${ }^{8,9)}$ The results of Xray diffraction patterns and transmission electron microscopy showed that $\mathrm{M}_{5} \mathrm{C}_{2}$ carbide precipitated after LTC when the carbon content exceeded 12 at $\%$ and no chromium carbide formed. ${ }^{6,10)}$ As a result, the surface hardness of austenitic stainless steels increases significantly without losing the good corrosion resistance. ${ }^{11)}$

\footnotetext{
${ }^{* 1}$ Graduate Student, National Taiwan University.

${ }^{* 2}$ Corresponding author, E-mail: kshwang@ntu.edu.tw
}

In previous studies, LTC was applied to fully dense wrought parts. Since the diffusion rate of carbon is quite low at low temperatures, the diffusion depth of carbon is quite shallow. Thus, the improvement in bulk properties of carburized austenitic stainless steels is limited. ${ }^{7)}$ However, typical pressed-and-sintered structural parts, with a density smaller than $7.25 \times 10^{3} \mathrm{~kg} / \mathrm{m}^{3}$ (92\% of theoretical density), which is the threshold where interconnected open pores begin to close, should allow carbon to permeate into the center of the parts during LTC and carburize exposed metal surfaces. Thus, not only the outer surface of the part will get carburized, but all pore channels should also be hardened. To our knowledge, no information has been reported on the properties of porous austenitic stainless steels treated with LTC. Thus, the objective of this study was to produce sintered 316L and 304L stainless steels with high hardness and tensile strength without losing the inherent good corrosion resistance.

\section{Experimental Procedures}

The morphologies and characteristics of as-received 316L and $304 \mathrm{~L}$ stainless steel powders used in this study are given in Fig. 1 and Table 1, respectively. To prepare the specimens, stainless steel powders were compacted into tensile bars following the Metal Powder Industries Federation (MPIF) Standard 10. Three green densities, 6.4, 6.6, and $6.8 \times 10^{3}$ $\mathrm{kg} / \mathrm{m}^{3}$, were prepared. Sintering was carried out at 1523 and $1623 \mathrm{~K}$ for $7.2 \mathrm{ks}$ under vacuum. The densities of sintered specimens were measured using the Archimedes method (MPIF Standard 54). Sintered stainless steels were carburized using the drip-feed method. Liquid methanol was fed into a furnace at a temperature of $1203 \mathrm{~K}$, in which the methanol decomposed and produced $\mathrm{CO}$ and $\mathrm{H}_{2}$ following the reaction below. ${ }^{12)}$

$$
\mathrm{CH}_{3} \mathrm{OH}_{(\mathrm{l})} \rightarrow \mathrm{CO}_{(\mathrm{g})}+2 \mathrm{H}_{2(\mathrm{~g})}
$$



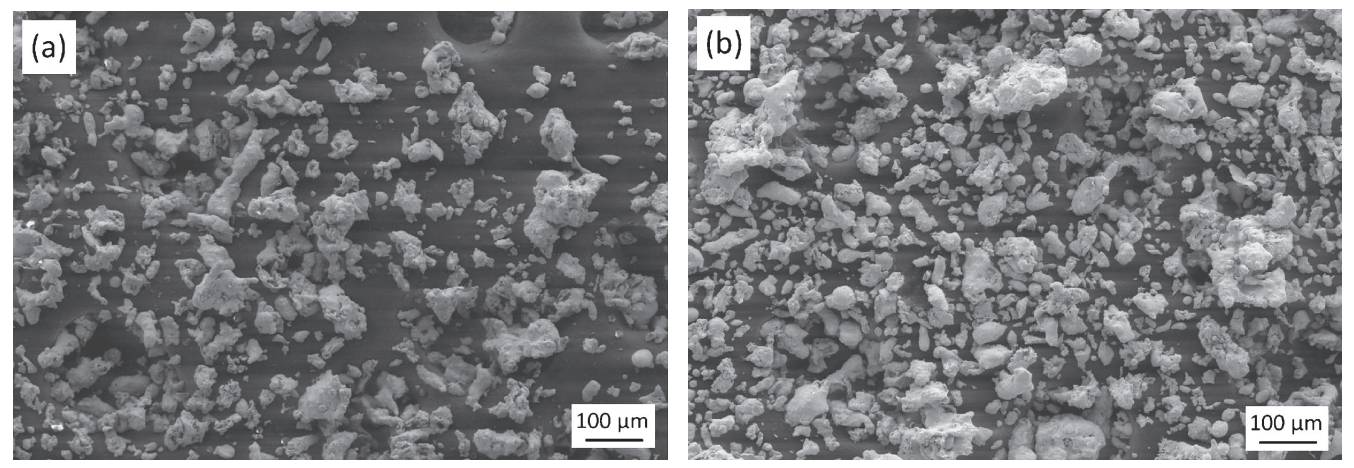

Fig. 1 The morphologies of the stainless steel powders used in this study. (a) 316L (b) 304L.

Table 1 The characteristics of $316 \mathrm{~L}$ and $304 \mathrm{~L}$ powders used in this study.

\begin{tabular}{|c|c|c|c|}
\hline & acteristics & $316 \mathrm{~L}$ & $304 \mathrm{~L}$ \\
\hline \multirow{3}{*}{\multicolumn{2}{|c|}{$\begin{array}{l}\text { Particle Size Distribution, } \mu \mathrm{m} \\
\text { (laser scattering) }\end{array}$}} & $D_{10}=18.3$ & $D_{10}=19.6$ \\
\hline & & $D_{50}=39.7$ & $D_{50}=40.2$ \\
\hline & & $D_{90}=86.7$ & $D_{90}=78.0$ \\
\hline \multicolumn{2}{|c|}{ Pycnometer Density, $\mathrm{kg} / \mathrm{m}^{3}$} & $7.89 \times 10^{3}$ & $7.85 \times 10^{3}$ \\
\hline \multirow[t]{8}{*}{ Chemistry } & $\mathrm{Cr}, \operatorname{mass} \%$ & 16.40 & 17.55 \\
\hline & $\mathrm{Ni}, \operatorname{mass} \%$ & 13.31 & 8.80 \\
\hline & Mo, mass $\%$ & 2.20 & - \\
\hline & $\mathrm{Mn}, \operatorname{mass} \%$ & 2.00 & 2.01 \\
\hline & $\mathrm{Si}$, mass $\%$ & 0.41 & 0.51 \\
\hline & $\mathrm{C}, \operatorname{mass} \%$ & 0.025 & 0.025 \\
\hline & $\mathrm{N}, \operatorname{mass} \%$ & 0.086 & 0.043 \\
\hline & $\mathrm{O}$, mass $\%$ & 0.333 & 0.390 \\
\hline
\end{tabular}

The CO gas produced was then fed into a tube furnace to carburize the outer surface of sintered specimens and the internal pore surface at $773 \mathrm{~K}$ for $86.4 \mathrm{ks}$. The bulk hardness of the carburized specimen was measured before and after LTC using a Rockwell hardness tester (ARK-600, Mitutoyo Co., Tokyo, Japan). Microhardness measurements were also performed using a Vickers micro-hardness tester (Micro Vickers Hardness Testing Machine, HM-112, Mitutoyo Co., Tokyo, Japan) at a $10 \mathrm{~g}$ loading. Tensile properties were determined using a universal tensile tester (AG-10TE, Shimadzu Co., Kyoto, Japan). The total carbon content before and after LTC was determined using a carbon analyzer (EMIA-220V, Horiba, Kyoto, Japan). To evaluate the corrosion resistance, specimens were immersed in a $2 \%$ $\mathrm{H}_{2} \mathrm{SO}_{4}$ solution at room temperature for $86.4 \mathrm{ks}$. The weight loss was then measured and a rating was given following the MPIF Standard 35. For microstructure observations, polished specimens were etched with aqua regia $\left(25 \% \mathrm{HNO}_{3}\right.$ and $75 \%$ $\mathrm{HCl})$ and then with Kalling's agent $\left(5 \mathrm{~g} \mathrm{CuCl}_{2}, 40 \mathrm{ml} \mathrm{HCl}\right.$, and $30 \mathrm{ml}$ water). After etching, the carburized region was white in color under an optical microscope, while the rest of the area was dark. The fracture surfaces of the tensile specimens with and without LTC were also examined using a scanning electron microscope (LEO-1530, LEO Electron Microscopy Ltd., Cambridge, United Kingdom). To identify the lattice parameter of the specimens, a high power monochromatized X-ray diffractometer (TTRAXIII, Rigaku Co., Tokyo) with $\mathrm{Cu}$ radiation was employed using an acceleration voltage of $50 \mathrm{kV}$ and working current of $300 \mathrm{~mA}$.

\section{Results and Discussion}

Table 2 shows that the densities of all 316L specimens increased after sintering. All densities were below $7.25 \times$ $10^{3} \mathrm{~kg} / \mathrm{m}^{3}$. As the sintered density increased, the hardness, tensile strength, and elongation improved. The corrosion resistance also improved because pores induce a crevice corrosion effect. After LTC, the sintered densities of the specimens did not change. However, the hardness and tensile strength improved significantly. For example, the specimen with the lowest sintered density, $6.71 \times 10^{3} \mathrm{~kg} / \mathrm{m}^{3}$, increased in hardness from 25 to 75 HRB (from HV70 to HV137) and in tensile strength from 295 to $520 \mathrm{MPa}$. For the high sintered density specimens, the level of improvement was less, but still obvious. For the specimen with the highest sintered density, $7.22 \times 10^{3} \mathrm{~kg} / \mathrm{m}^{3}$, the hardness increased from 45 to 56 HRB (from HV87 to HV101) and the tensile strength increased from 390 to $421 \mathrm{MPa}$ after LTC. It was noticed that, after LTC, the hardness and tensile strength of the high density part were lower than those with low densities. The main reason was that more pores were present in the low density specimens and the degree of interconnectivity of pore channels was also higher; thus more pore surfaces and deeper sections of the part could be carburized. In comparison, in the compact with a high sintered density of $7.22 \times 10^{3} \mathrm{~kg} / \mathrm{m}^{3}$, some of the pores were closed. As a result, less carbon was contained, as shown in Table 2, and the carburization depth was shallower after LTC. Despite the increase in the carbon content of all specimens after LTC, their corrosion resistance remained unchanged. The only deterioration in properties was elongation due to the increase in hardness.

Table 3 shows the properties of sintered 304L before and after LTC. The changes of the properties of 304L followed the same trend as those of the $316 \mathrm{~L}$ shown in Table 2. The hardness and tensile strength of the low density specimen increased more significantly and were higher than those of high density parts. For the specimen with a sintered density of $6.70 \times 10^{3} \mathrm{~kg} / \mathrm{m}^{3}$, the hardness increased from 27 to $74 \mathrm{HRB}$ (from HV72 to HV135) and tensile strength increased from 291 to $519 \mathrm{MPa}$. The corrosion resistances of the as-sintered specimens were all rated 1, which is poorer than that of the $316 \mathrm{~L}$ due to the difference in composition. After LTC, the corrosion resistance deteriorated slightly from rating 1 to rating 2 .

Figures 2(a) and 2(b) show, respectively, the profiles of the micro-hardness from the surface to the center of $316 \mathrm{~L}$ and 
Table 2 Green density $\left(\rho_{\mathrm{g}}\right)$, sintering temperature $(T)$, sintered density $\left(\rho_{\mathrm{s}}\right)$, hardness, tensile strength (UTS), elongation $(\varepsilon)$, carbon content $(C)$, and corrosion resistance of sintered $316 \mathrm{~L}$ before and after LTC.

\begin{tabular}{|c|c|c|c|c|c|c|c|c|}
\hline Material & $\begin{array}{c}\rho_{\mathrm{g}} \\
\mathrm{kg} / \mathrm{m}^{3}\end{array}$ & $\begin{array}{l}T, \\
\mathrm{~K}\end{array}$ & $\begin{array}{c}\rho_{\mathrm{s}} \\
\mathrm{kg} / \mathrm{m}^{3}\end{array}$ & $\begin{array}{c}\text { Hardness, } \\
\text { HRB }\end{array}$ & $\begin{array}{l}\text { UTS, } \\
\mathrm{MPa}\end{array}$ & $\begin{array}{l}\varepsilon \\
\%\end{array}$ & $\begin{array}{c}C, \\
\operatorname{mass} \%\end{array}$ & $\begin{array}{c}\text { Corrosion } \\
\text { Rating* }\end{array}$ \\
\hline \multirow{4}{*}{$\begin{array}{l}316 \mathrm{~L} \\
\text { before LTC }\end{array}$} & 6400 & 1523 & 6710 & 25 & 295 & 24 & 0.004 & 1 \\
\hline & 6600 & 1523 & 6890 & 36 & 329 & 28 & 0.007 & 1 \\
\hline & 6800 & 1523 & 7100 & 44 & 354 & 32 & 0.003 & 0 \\
\hline & 6800 & 1623 & 7220 & 45 & 390 & 38 & 0.002 & 0 \\
\hline \multirow{4}{*}{$\begin{array}{l}316 \mathrm{~L} \\
\text { after LTC }\end{array}$} & 6400 & 1523 & 6710 & 75 & 520 & 20 & 0.640 & 1 \\
\hline & 6600 & 1523 & 6890 & 72 & 510 & 22 & 0.516 & 1 \\
\hline & 6800 & 1523 & 7100 & 71 & 503 & 26 & 0.423 & 0 \\
\hline & 6800 & 1623 & 7220 & 56 & 421 & 36 & 0.130 & 0 \\
\hline
\end{tabular}

*0: mass loss: $<0.024 \mathrm{~g} / \mathrm{dm}^{2} /$ day, 1 : mass loss: $0.024-0.24 \mathrm{~g} / \mathrm{dm}^{2} /$ day

Table 3 Green density $\left(\rho_{\mathrm{g}}\right)$, sintering temperature $(T)$, sintered density $\left(\rho_{\mathrm{s}}\right)$, hardness, tensile strength (UTS), elongation $(\varepsilon)$, carbon content $(C)$, and corrosion resistance of $304 \mathrm{~L}$ before and after LTC.

\begin{tabular}{|c|c|c|c|c|c|c|c|c|}
\hline Material & $\begin{array}{c}\rho_{\mathrm{g}}, \\
\mathrm{kg} / \mathrm{m}^{3}\end{array}$ & $\begin{array}{l}T, \\
\mathrm{~K}\end{array}$ & $\begin{array}{c}\rho_{\mathrm{s}} \\
\mathrm{kg} / \mathrm{m}^{3}\end{array}$ & $\begin{array}{l}\text { Hardness, } \\
\text { HRB }\end{array}$ & $\begin{array}{l}\text { UTS, } \\
\mathrm{MPa}\end{array}$ & $\begin{array}{l}\varepsilon \\
\%\end{array}$ & $\begin{array}{c}C, \\
\operatorname{mass} \%\end{array}$ & $\begin{array}{c}\text { Corrosion } \\
\text { Rating* }\end{array}$ \\
\hline \multirow{4}{*}{$\begin{array}{l}\text { 304L } \\
\text { before LTC }\end{array}$} & 6400 & 1523 & 6700 & 27 & 291 & 25 & 0.009 & 1 \\
\hline & 6600 & 1523 & 6870 & 37 & 335 & 30 & 0.003 & 1 \\
\hline & 6800 & 1523 & 7090 & 42 & 351 & 32 & 0.010 & 1 \\
\hline & 6800 & 1623 & 7200 & 44 & 388 & 40 & 0.003 & 1 \\
\hline \multirow{4}{*}{$\begin{array}{l}304 \mathrm{~L} \\
\text { after LTC }\end{array}$} & 6400 & 1523 & 6700 & 74 & 519 & 16 & 0.690 & 2 \\
\hline & 6600 & 1523 & 6870 & 75 & 511 & 18 & 0.591 & 2 \\
\hline & 6800 & 1523 & 7090 & 75 & 510 & 25 & 0.440 & 2 \\
\hline & 6800 & 1623 & 7200 & 53 & 416 & 38 & 0.140 & 1 \\
\hline
\end{tabular}

${ }^{*} 0$ : mass loss: $<0.024 \mathrm{~g} / \mathrm{dm}^{2} /$ day, $1:$ mass loss: $0.024-0.24 \mathrm{~g} / \mathrm{dm}^{2} /$ day, 2 : mass loss: $0.24-2.4 \mathrm{~g} / \mathrm{dm}^{2} / \mathrm{day}$

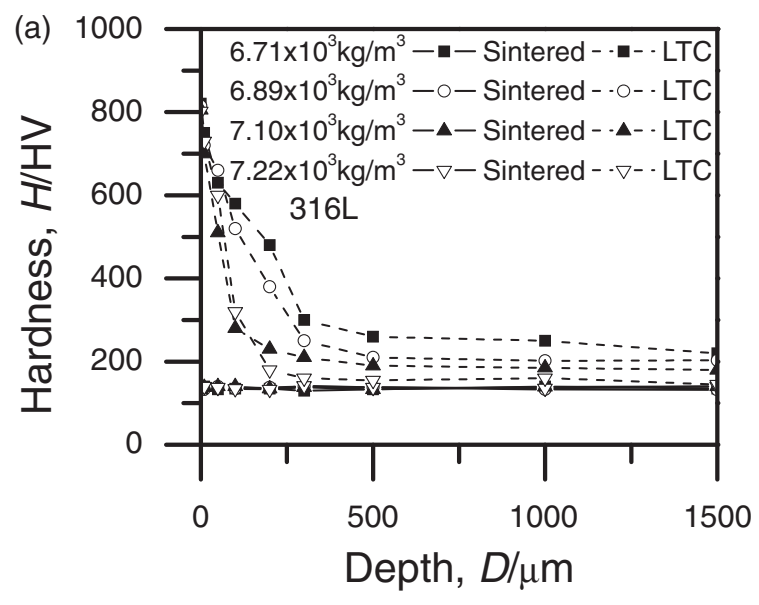

(b) $1000-6.70 \times 10^{3} \mathrm{~kg} / \mathrm{m}^{3}-\mathrm{m}-$ Sintered - - - LTC

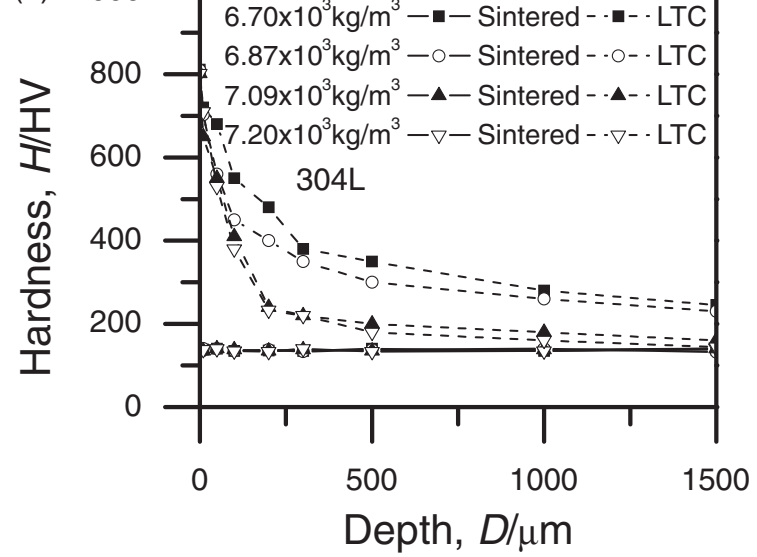

Fig. 2 The depth profiles of micro-hardness of (a) 316L and (b) 304L before and after LTC.
304L before and after LTC. The hardness values at the surface and at the center of as-sintered $316 \mathrm{~L}$ and $304 \mathrm{~L}$ were about HV135. For the $316 \mathrm{~L}$ with a low sintered density of $6.71 \times 10^{3} \mathrm{~kg} / \mathrm{m}^{3}$, the hardness values at the surface and center were HV820 and HV220, respectively, after LTC. Using the hardness of HV550 as the criterion, the carburization depth was about $130 \mu \mathrm{m}$. For the $316 \mathrm{~L}$ with a high sintered density of $7.22 \times 10^{3} \mathrm{~kg} / \mathrm{m}^{3}$, the surface hardness was HV802 after LTC, similar to that of the low density specimen. However, the carburized depth decreased to $55 \mu \mathrm{m}$, and the center hardness was only HV145. These results agree with those shown in Table 2, in which high density parts had lower bulk hardness after LTC. These results are also similar to those obtained for steam-treated sintered compacts, ${ }^{13)}$ in which hard magnetite forms at pore surfaces due to the reaction between steam and the iron matrix. For parts with low densities, the center hardness can be higher than that of high density parts after steam treatment.

The form of the depth profile of the micro-hardness of 304L, as shown in Fig. 2(b), was similar to that of 316L. The surface hardness increased obviously after LTC and was about HV800 irrespective of the sintered density. But the center hardness values of parts with the lowest sintered density were higher than that of the specimen with the highest sintered density.

Figures 3 and 4 show the microstructures of 316L and 304L, respectively, after LTC. The white areas are the carburized regions. It can be seen in Fig. 3 that the center of the specimen with a sintered density of $6.71 \times 10^{3} \mathrm{~kg} / \mathrm{m}^{3}$ was carburized after LTC, indicating that carbon had diffused 

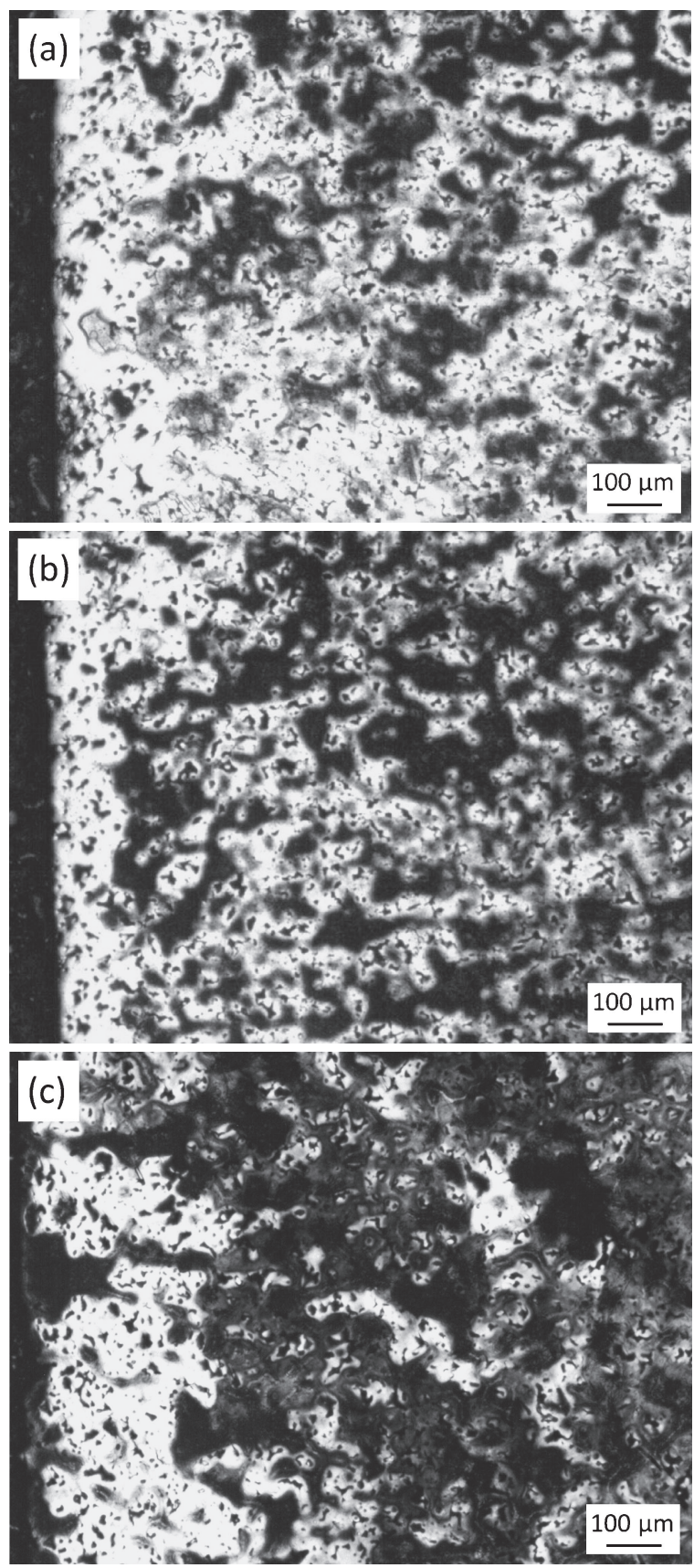

Fig. 3 The microstructures of pressed-and-sintered 316L with different sintered densities after LTC. White areas are the carburized regions. (a) $6.71 \times 10^{3} \mathrm{~kg} / \mathrm{m}^{3}$ (b) $6.89 \times 10^{3} \mathrm{~kg} / \mathrm{m}^{3}$ (c) $7.22 \times 10^{3} \mathrm{~kg} / \mathrm{m}^{3}$.

into this region through the numerous interconnected pores. In contrast, the specimen with a sintered density of $7.22 \times 10^{3} \mathrm{~kg} / \mathrm{m}^{3}$ had only a few carburized areas in the center due to the smaller number of open pore channels. The same phenomenon can also be observed in Fig. 4 in the 304L specimens.

To further analyze the carburized layers, the microstructure of the center region in $316 \mathrm{~L}$ specimens with a density of $6.89 \times 10^{3} \mathrm{~kg} / \mathrm{m}^{3}$ was examined at higher magnifications, as shown in Fig. 5. It is obvious that the carburized layer (white region) formed around the pore and had a hardness of about HV241, higher than the HV138 in the non-carburized cores. For examination of the structural changes in carburized layers, Fig. 6 shows the X-ray diffraction pattern of the
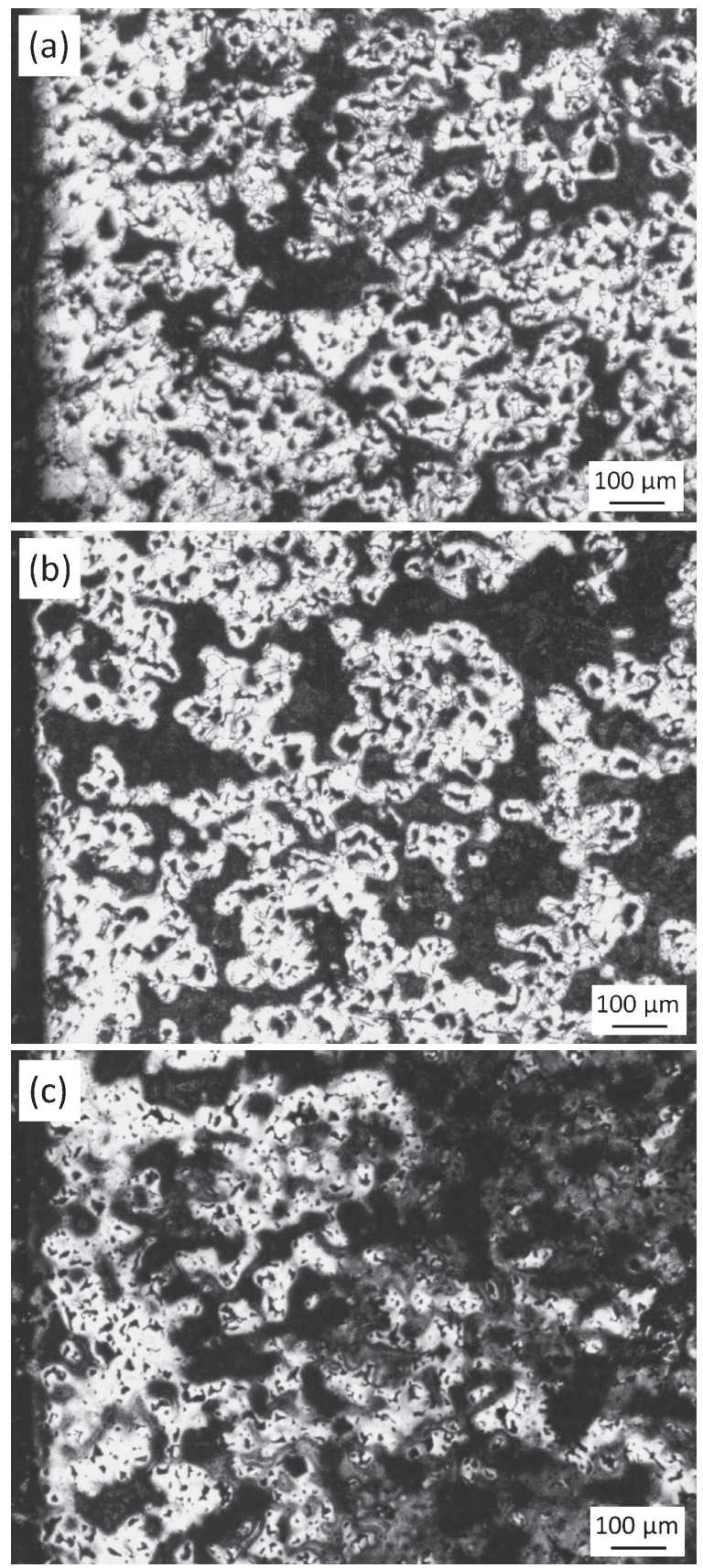

Fig. 4 The microstructures of pressed-and-sintered 304L with different sintered densities after LTC. White areas are the carburized regions.

(a) $6.70 \times 10^{3} \mathrm{~kg} / \mathrm{m}^{3}$ (b) $6.87 \times 10^{3} \mathrm{~kg} / \mathrm{m}^{3}$ (c) $7.20 \times 10^{3} \mathrm{~kg} / \mathrm{m}^{3}$.

sintered 316L with different densities before and after LTC treatment. It is clear that the two main diffraction peaks of the specimen shifted after LTC to lower angles as the sintered density decreased. The calculated lattice parameters, as shown in Fig. 7, indicate that the amount of expansion increased more in low sintered density parts, as a result of the more complete carburization and the presence of more $\mathrm{M}_{5} \mathrm{C}_{2}$.

These microstructures confirm that the interconnected pores provide the necessary conduits for carbon to diffuse into the center of sintered compacts and form carburized layers during LTC. Since pores are usually the crack initiation sites during mechanical testing, the hardened carburized layers at pore surfaces thus increase the strength of tensile specimens after LTC, as shown in Tables 2 and 3. Figure 8 of 


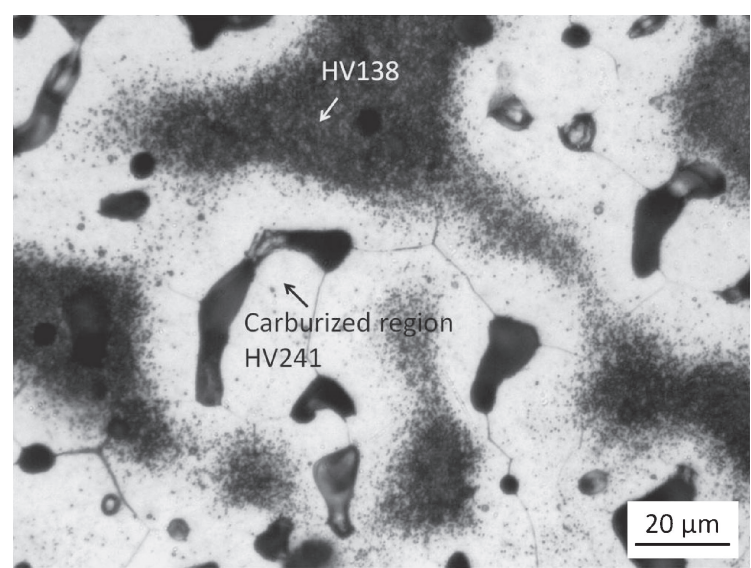

Fig. 5 The microstructure in the center of pressed-and-sintered $316 \mathrm{~L}$ with a sintered density of $6.89 \times 10^{3} \mathrm{~kg} / \mathrm{m}^{3}$ after LTC. White areas around the pores are the carburized regions with high hardness.

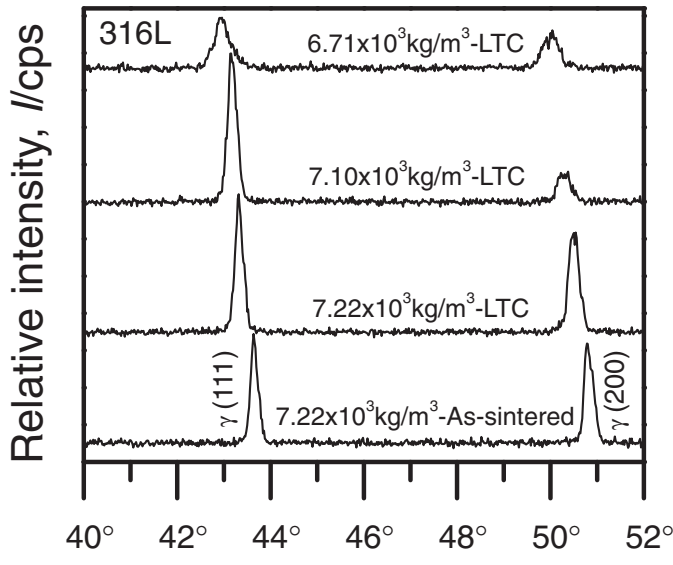

$2 \theta$

Fig. 6 The XRD patterns of $316 \mathrm{~L}$ stainless steels with different sintered densities after LTC.

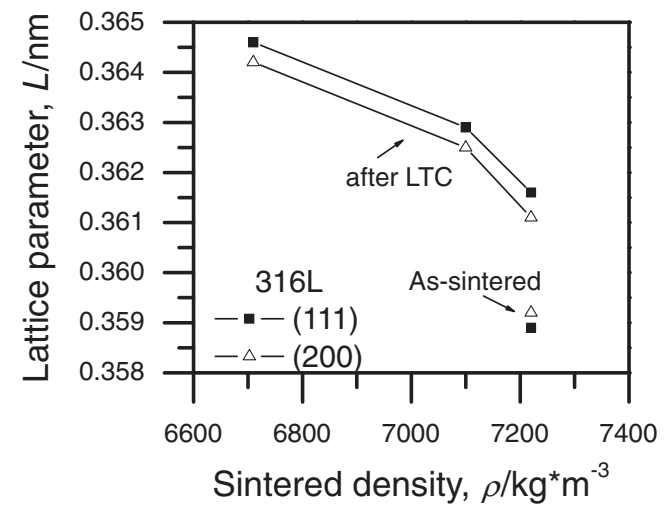

Fig. 7 The lattice parameters of 316L stainless steels with different sintered densities after LTC, showing that the amount of lattice expansion was larger in the specimen with a lower density after LTC.

the fracture surfaces of the pressed-and-sintered $316 \mathrm{~L}$ before and after LTC indicates typical ductile morphology and dimples. Nonetheless, small amounts of cleavage planes were observed after LTC, as shown in Fig. 8(b), especially in areas with small section thicknesses, since the majority of these sections had been carburized, which made the material hard and brittle.
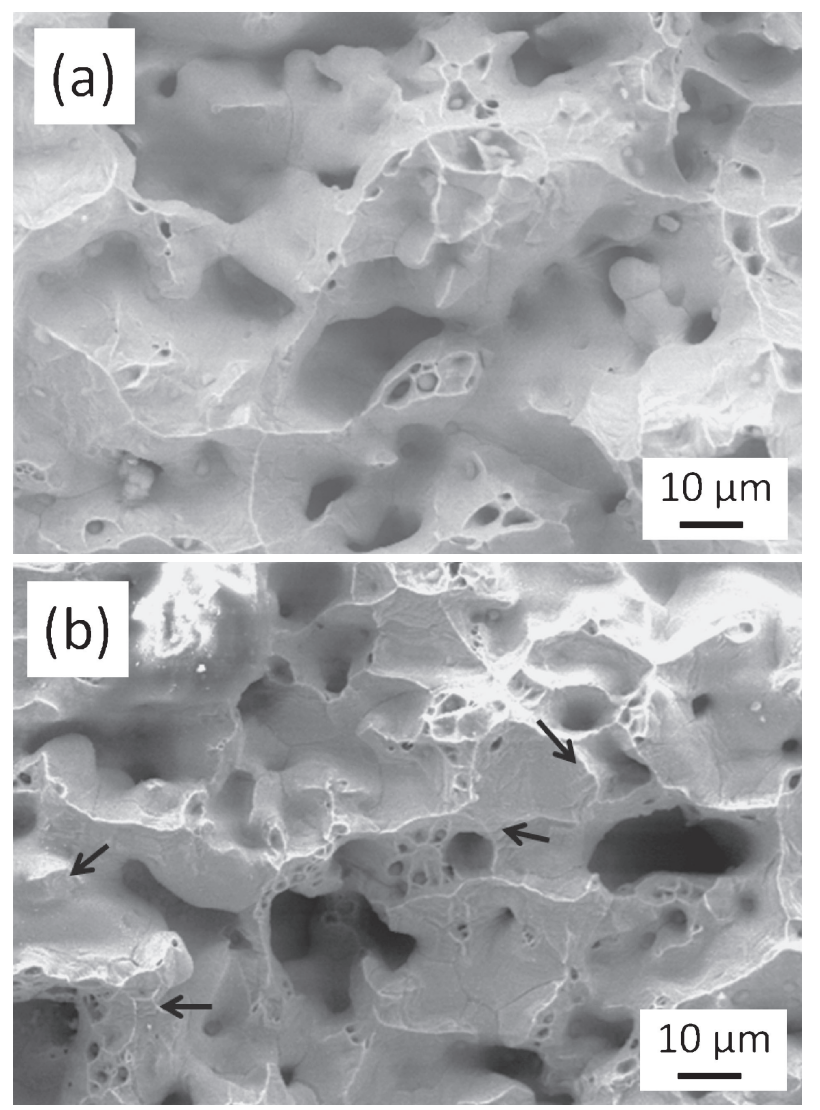

Fig. 8 The fracture surface of pressed-and-sintered 316L with a density of $6.89 \times 10^{3} \mathrm{~kg} / \mathrm{m}^{3}$, showing some cleavage planes (indicated by arrows) after LTC. (a) as-sintered (b) after LTC.

\section{Conclusions}

In the fully dense parts, the LTC can harden the surface only to a limited depth; in pressed-and-sintered 316L and 304L compacts containing interconnected pores, LTC can significantly improve the tensile strength and hardness. These improvements may broaden the applications of these materials, in particular in structural parts, which was formerly impossible due to the poor wear resistance and low loadbearing capabilities. The following is a summary of the changes of mechanical properties and structures in sintered compacts after LTC.

(1) Carbon can diffuse deeper into the center of the lowdensity specimen during LTC due to the presence of more interconnected pores. Thus, the level of improvement depends on the porosity, and the tensile strength and hardness of low-density parts can even surpass those of high-density parts after LTC.

(2) For pressed-and-sintered $316 \mathrm{~L}$ compacts with a density of $6.71 \times 10^{3}$ and $7.22 \times 10^{3} \mathrm{~kg} / \mathrm{m}^{3}$, the hardness increased from 25 to $75 \mathrm{HRB}$ (from HV70 to HV137) and from 45 to $56 \mathrm{HRB}$ (from HV87 to HV101), respectively, after LTC treatment. The tensile strength increased from 295 to $520 \mathrm{MPa}$ and from 390 to $421 \mathrm{MPa}$. The hardness and tensile strength of low sintered density parts are higher than those of high density parts. 
(3) The 304L showed similar results. For sintered 304L compacts with a density of $6.70 \times 10^{3}$ and $7.20 \times$ $10^{3} \mathrm{~kg} / \mathrm{m}^{3}$, the hardness increased from 27 to $74 \mathrm{HRB}$ (from HV72 to HV135) and from 44 to $53 \mathrm{HRB}$ (from HV86 to HV96), respectively, after LTC treatment. The tensile strength increased from 291 to $519 \mathrm{MPa}$ and from 388 to $416 \mathrm{MPa}$.

(4) The microstructure examinations indicate that the carburized layer in $316 \mathrm{~L}$ compacts examined in this study is between 55 and $130 \mu \mathrm{m}$ thick when LTC is performed at $773 \mathrm{~K}$ for $86.4 \mathrm{ks}$.

(5) The X-ray diffraction patterns show that the amount of lattice expansion increases as the sintered density decreases.

\section{Acknowledgement}

The authors wish to thank the Taiwan Powder Technologies Co. for their financial support of this work. We also thank Lenco Enterprises Co. and Professor Yong-Chwang Chen for providing stainless steel powders and carburizing instruments.

\section{REFERENCES}

1) E. Klar and P. K. Samal: Powder Metallurgy Stainless Steels, (ASM International, Materials Park, OH, 2007) pp. 185-201.

2) MPIF Standard 35: Materials Standards for PM Structural Parts, 2009.

3) A. H. Heuer, F. Ernst, H. Kahn, A. Avishai, G. M. Michal, D. J. Pitchure and R. E. Ricker: Scr. Mater. 56 (2007) 1067-1070.

4) G. M. Michal, F. Ernst and A. H. Heuer: Metall. Mater. Trans. A 37A (2006) 1819-1824.

5) G. M. Michal, X. Gu, W. D. Jennings, H. Kahn, F. Ernst and A. H. Heuer: Metall. Mater. Trans. A 40A (2009) 1781-1790.

6) Y. Cao, F. Ernst and G. M. Michal: Acta Mater. 51 (2003) 4171-4181.

7) G. M. Michal, F. Ernst, H. Kahn, Y. Cao, F. Oba, N. Agarwal and A. H. Heuer: Acta Mater. 54 (2006) 1597-1606.

8) H. Kahn, G. M. Michal, F. Ernst and A. H. Heuer: Metall. Mater. Trans. A 40A (2009) 1799-1804.

9) T. L. Christiansen and M. A. J. Somers: Metall. Mater. Trans. A 40A (2009) 1791-1798.

10) F. Ernst, Y. Cao and G. M. Michal: Acta Mater. 52 (2004) 1469-1477.

11) F. J. Martin, P. M. Natishan, E. J. Lemieux, T. M. Newbauer, R. J. Rayne, R. A. Bayles, H. Kahn, G. M. Michal, F. Ernst and A. H. Heuer: Metall. Mater. Trans. A 40A (2009) 1805-1810.

12) J. Slycke and L. Sproge: J. Heat Treat. 5 (1988) 97-114.

13) R. M. German: Powder Metallurgy of Iron and Steel, (John Wiley \& Sons Inc., New York, NY, 1998) pp. 336-340. 